MRS ULLA GRETA HARJUNMAA (Orcid ID : 0000-0003-0598-3918)

Article type : Original Manuscript

\title{
Periapical infection may affect birth outcomes via systemic inflammation
}

Running title: Apical infection, inflammation and birth outcomes

${ }^{1}$ Harjunmaa U, ${ }^{2,6}$ Doyle R, ${ }^{3}$ Järnstedt J, ${ }^{4}$ Kamiza S, ${ }^{5}$ Jorgensen JM, ${ }^{5}$ Stewart CP, ${ }^{6}$ Shaw L, ${ }^{1}$ Hallamaa

L, ${ }^{1}$ Ashorn U, ${ }^{6}$ Klein N, ${ }^{5}$ Dewey KG, ${ }^{7}$ Maleta K, ${ }^{1}$ Ashorn P

1. Center for Child Health Research, University of Tampere Faculty of Medicine and Life Sciences and Tampere University Hospital, Tampere, Finland

2. Microbiology, Virology \& Infection Control, Great Ormond Street Hospital NHS Foundation Trust, London, United Kingdom

3. Tampere University Hospital, Medical Imaging Center, Department of Radiology, Tampere, Finland

4. Department of Pathology, University of Malawi College of Medicine, Blantyre, Malawi

5. Program in International and Community Nutrition, Department of Nutrition, University of California, Davis, Davis, California, USA

6. Institute of Child Health, University College London, London, United Kingdom

7. University of Malawi College of Medicine, Department of Community Health, Blantyre, Malawi

\section{Key words:}

Apical infection, systemic inflammation, placental infection, duration of pregnancy, birth size

\section{Correspondence to:}

Ulla Harjunmaa

Address: University of Tampere Faculty of Medicine and Life Sciences, Arvo-building, FIN-33014 University of Tampere, Finland. Telephone: +358 50 4039849. Email: ulla.harjunmaa@fimnet.fi

Date of submission: 21.08 .2017

This article has been accepted for publication and undergone full peer review but has not been through the copyediting, typesetting, pagination and proofreading process, which may lead to differences between this version and the Version of Record. Please cite this article as doi: 10.1111/odi.12817

This article is protected by copyright. All rights reserved. 


\section{ABSTRACT}

Objectives: Maternal dental periapical infections are associated with preterm birth and intrauterine growth restriction. This study investigates if the association is mediated through bacterial spread from periapical lesions to placenta (direct pathway) or systemic inflammatory reaction (indirect pathway).

Materials and Methods: We compared birth outcomes in Malawian mothers with and without periapical infection. As markers of a direct pathway, we identified placental bacteria using a $16 \mathrm{~S}$ rDNA approach, and assessed histological evidence of inflammation in the placenta and amniotic membranes. We measured C-reactive protein, alpha-1-acid glycoprotein and salivary cortisol as markers of an indirect pathway. We used regression models to associate the predictor variables with duration of pregnancy and newborn size.

Results: Of 1024 women, $23.5 \%$ had periapical infection. There was no association of periapical infection with either bacterial DNA or histological inflammation in placenta or membranes. Periapical infection was associated with C-reactive protein, alpha-1-acid glycoprotein and cortisol concentrations in a dose-dependent manner at 36wk. Addition of alpha-1-acid glycoprotein or cortisol concentration into regression models attenuated the association between periapical infection and pregnancy outcomes.

Conclusion: There was no evidence of direct spread of periapical bacteria to the placenta. Periapical infections and adverse pregnancy outcomes is in part mediated through systemic inflammation.

This article is protected by copyright. All rights reserved. 


\section{INTRODUCTION}

Every year 32 million infants are born too early or too small for their gestational age (Lee et al., 2013). Of the 3.1 million annual global neonatal deaths, $35 \%$ are related to preterm birth (PTB) complications (Liu et al., 2012). The survivors are at risk of severe long term morbidity and development delay (Saigal \& Doyle, 2008). Current interventions have largely failed to substantially impact the frequency of PTB and intrauterine growth restriction (IUGR) and indeed, PTB rates are still increasing in many countries (Chang et al., 2013). Several risk factors for PTB and IUGR have been identified of which maternal infections are among the most important. Yet the actual mechanisms by which these risk factors affect pregnancy are unclear (Goldenberg, Culhane, lams, \& Romero, 2008) which hampers the development of new, effective preventive approaches.

Our previous study results from Malawi indicated an association between maternal dental periapical infections (PAI) and shorter pregnancy duration and smaller birth size (Harjunmaa et al., 2015). PAI commonly develops when a deep caries lesion exposes the pulp of the tooth allowing oral bacteria to enter the dental root canals, from where the infection eventually spreads to the bone surrounding the root (Nair, 2004). A causal relationship between PAI and pregnancy outcomes could be through both direct and indirect pathways, which are not mutually exclusive. Firstly, a direct pathway could exist whereby oral bacteria are disseminated through the blood stream to placental and fetal tissues, influencing birth outcomes through the generation of local inflammation, tissue damage or changes in placental function (Han \& Wang, 2013; Romero, Dey, \& Fisher, 2014). Secondly, bacteria within the oral cavity, could induce a systemic inflammatory response that could affect the pregnancy indirectly. Although earlier studies have shown that bacteria can translocate from mouth to placenta (Aagaard et al., 2014), and it is known that PAl may lead to systemic inflammation (Gomes et al., 2013), there is no evidence that pathways from PAl to pregnancy

This article is protected by copyright. All rights reserved. 
complications actually exist. If they do, prevention and treatment of dental caries, the most common chronic disease globally that usually precedes PAI (Marcenes et al., 2013), would be a new and feasible intervention for prevention of PTB and IUGR.

This study aimed to assess whether there is evidence of these two biologically plausible pathways between PAI and adverse pregnancy outcomes in a cohort of pregnant women from the iLiNS-DYAD study in Malawi (Harjunmaa et al., 2015). Our main hypothesis was that the associations between PAl and shortened duration of pregnancy, lower birth weight and smaller neonatal size are mediated through spread of the periapical bacteria to the feto-placental unit (direct pathway) or systemic inflammation (indirect pathway). We examined the direct pathway by assessing the prevalence and quantity of histological inflammation and bacteria in the placenta and chorioamniotic membranes. The indirect pathway was assessed by measuring concentrations of serum C-reactive protein (CRP) and alpha-1-acid glycoprotein (AGP) and salivary cortisol during pregnancy. CRP and AGP are acute phase proteins, produced in the liver in response to inflammatory stimuli, and have been associated with shortened duration of gestation and IUGR (Pitiphat et al., 2005; Tjoa et al., 2003). Cortisol is a steroid hormone released from the adrenal glands in response to emotional, physical or immunological stress (Bellavance \& Rivest, 2014) and it also regulates the maintenance of pregnancy and the timing of parturition (Giurgescu, 2009; Voltolini \& Petraglia, 2014). In this study, we investigated if the shortened duration of pregnancy, smaller infant birth weight and neonatal size in women with PAI were mediated through these pathways.

This article is protected by copyright. All rights reserved. 


\section{METHODS}

\section{Study design, outcomes and ethics statement}

The present study represents continued analysis of a cross-sectional oral health sub-study that was nested within a randomized, controlled intervention trial, iLiNS-DYAD-M, in Malawi, Sub-Saharan Africa (ClinicalTrials.gov, identifier NCT01239693). The trial was designed to examine the impact of home-fortification of pregnant women's diets with lipid-based nutrient supplements on pregnancy outcomes and maternal and child health in a rural African community. Participants were enrolled prospectively into the main trial and followed throughout pregnancy. The oral health examination to assess the association between oral infections and birth outcomes was conducted after delivery.

The outcome measures for the current study were duration of pregnancy, birth weight, neonatal length and neonatal head circumference. The potential intermediary variables were CRP, AGP and cortisol concentrations at $14-20$ and at 36 gestation weeks (gw), prevalence of any or severe chorioamnionitis, prevalence of placental intervillositis, bacterial load and prevalence of common periapical bacteria in placental tissues and fetal membranes.

Written or thumb printed informed consent was taken from the participants at enrolment. Ethical approval was obtained from the College of Medicine Research and Ethics Committee, University of Malawi and the Ethics Committee of Pirkanmaa Hospital District, Finland (Protocol number P.08/10/972, date of approval $31^{\text {st }}$ January 2011)

This article is protected by copyright. All rights reserved. 


\section{Participants, enrollment and data collection}

Details of the main trial (Ashorn et al., 2015) and the oral health sub-study (Harjunmaa et al., 2015) have been published previously. In brief, we enrolled 1391 pregnant women attending antenatal care before 20 gestational weeks between February 2011 and August 2012 through four health facilities in Mangochi District, southern Malawi. Participants received intermittent preventive malaria treatment with sulfadoxine-pyrimethamine at their first antenatal visit and between 28 and 34 gw as part of standard Malawian antenatal care. Research personnel assessed the duration of pregnancy with ultrasonography, performed health- and antenatal examinations and recorded participants' medical and obstetric history and socioeconomic background. Participants who were enrolled in the main trial, had singleton pregnancies and completed the oral health examination were eligible for the oral health sub-study. Two dental therapists conducted full-mouth oral health examinations of the mothers and took digital panoramic radiographs of their jaws as soon as possible after delivery. A radiologist and an experienced dentists analysed the radiographs jointly. Research personnel recorded delivery events within $48 \mathrm{~h}$ after delivery and measured infant's birth weight (BW). At 1-6 weeks after delivery, anthropometrists measured infant's length, head circumference and neonatal weight.

Saliva and blood collection and processing

Research nurses collected saliva and venous blood samples at the study clinic at baseline (14-20 gw) and 36 gw. Saliva was collected after 30 min fast with a polymer swab placed under the tongue. Lab technicians measured salivary cortisol concentrations using an ELISA method and plasma CRP and AGP by immunoturbidimetry. Details of the saliva collection and processing are published elsewhere (Stewart et al., 2015).

This article is protected by copyright. All rights reserved. 
Placental tissue and fetal membrane collection and processing

Two pieces of the chorionic and amniotic membranes were cut from the edge of the rupture site, and two full thickness pieces of placental tissue from near the umbilical cord insertion. One placental and one membrane sample were fixed in $10 \%$ formalin, embedded in paraffin wax, cut and stained with haematoxylin \& eosin on glass slides for histological analysis. The remaining two samples were used for bacterial DNA analysis as published earlier (Doyle et al., 2017). In brief, all DNA extracted from the samples were screened for bacterial DNA using a qPCR targeting the V5-7 regions of the 16S rRNA gene (785F: 5'-GGATTAGATACCCBRGTAGTC-3', 1175R: 5'-ACGTCRTCCCCDCCTTCCTC-3'). Samples with detectable amounts of bacterial DNA were multiplexed, pooled, cleaned and sequenced. Paired-end sequenced reads were demultiplexed and assigned OTUs at $97 \%$ similarity against a small custom database of full length $16 \mathrm{~S}$ rDNA sequences. Any sequences that failed to match at $97 \%$ were assigned against the full Greengenes database.

\section{Definitions}

We diagnosed PAI if an unambiguous osteolytic finding $(>1 \mathrm{~mm})$ related to the dental root apex was seen in the radiographs. We graded PAI as not present or present. We considered that a participant had PAl if at least one finding was recorded. We determined mild to moderate PAI as 1-3 lesions and severe PAI as 4 lesions or more. We calculated infants' sex-age-standardized length-for-age (LAZ), weight-for-age (WAZ) and head circumference-for-age Z-scores using the WHO Child Growth Standards.

This article is protected by copyright. All rights reserved. 
We considered high CRP concentration as CRP $>5 \mathrm{mg} / \mathrm{L}$, high AGP concentration as AGP $>1 \mathrm{~g} / \mathrm{L}$ and high cortisol concentration as $>75^{\text {th }}$ centile of all cortisol concentrations at that time point. We defined histological chorioamnionitis as $\geq 5$ and severe chorioamnionitis as $\geq 25$ neutrophil granulocytes on average per 10 high power fields present in either the chorionic plate or the amniotic membrane. We defined acute intervillositis as $\geq 5$ neutrophils and chronic intervillositis as $\geq$ 5 lymphocytes or monocytes on average per 10 high power fields in the placental intervillous space. We assessed presence of bacteria in the placental or fetal membranes by $16 \mathrm{~S}$ rDNA broad-range SYBR green quantitative PCR assay. A result was positive for bacterial DNA if their Ct value was lower than $28 \pm 3$ cycles (equivalent to $40 \mathrm{CFU} / \mu \mathrm{l}$ ) depending on variation between runs and determined using calibration curves generated from serial dilution of a known amount of Escherichia coli culture.

\section{Statistical analysis}

We performed statistical analysis with Stata 12.1 (StataCorp, College Station, USA). We included in the analyses participants who completed the oral health visit within the 6 week puerperal period. The sample size was originally calculated for the main objective of the iLiNS-DYAD-M trial. In the current analyses, we used the same sample of 1024 women as in our previous analyses on oral infections and birth outcomes that offered approximately 93\% power to detect differences between the groups, assuming an infection prevalence of $25 \%$ and an effect size of 0.25 for continuous birth outcomes at 5\% two-sided type I error rate (Harjunmaa et al., 2015).

We used multivariate linear regression to estimate adjusted means for continuous outcomes, and modified Poisson regression models (Zou, 2004) to estimate adjusted proportions for binary outcomes, and to estimate the associations between PAI and inflammation or infection variables (except bacterial prevalence and mean loads) and cortisol. The same covariates that were considered potential confounders of the relationship between oral infections and birth outcomes in

This article is protected by copyright. All rights reserved. 
our previous study (Harjunmaa et al., 2015) were used in this study for all outcomes to make the estimates comparable. We considered that these covariates were also biologically plausible confounders for the inflammation outcomes. The covariates were included in the models using forced entry method. The included covariates were maternal age, height, body-mass-index, socioeconomic score (household assets), parity, time between delivery and the oral health examination, and number of teeth as continuous variables, and study site, nutrition intervention group, aenemia, HIV, malaria and periodontitis status as categorical variables. In addition, time between wake-up and saliva collection, and time between last meal and saliva collection were used in cortisol analysis models as continuous variables. We added square terms for maternal height, $\mathrm{BMI}$, age and socioeconomic score into the models to test the assumption of linear relationships between continuous outcomes and covariates. Because adding non-linear covariates did not markedly improve the adjusted R-square, we excluded the non-linear terms from the final models. To assess if an inflammation variable was on a pathway between PAI and birth outcomes, we added those variables that were associated with PAI severity one by one in the models. We used White's general test for heteroscedasticity to test for unequal variances using non-imputed data. The null hypothesis of homoscedasticity was not rejected.

We used multiple imputed data (50 imputations) based on chained equation methods (van Buuren, Boshuizen, \& Knook, 1999) for all multivariable model analyses. We imputed missing data for all variables that were included in the analyses, except for the $16 \mathrm{~S}$ rRNA data. Cortisol concentration at $28 w k$ was used in the imputation but not in the analyses themselves. The number of originally missing values that were substituted with values obtained by multiple imputation ranged from 0 to $371(0.0 \%$ to $36.2 \%)$ per variable (supplementary table 1$)$.

This article is protected by copyright. All rights reserved. 
We assessed the prevalence of any bacteria (bacterial 16S rRNA copies) in the placental and fetal membrane tissues by the PAI severity categories (no, mild-to-moderate and severe infection). Comparison between the groups was made with Fisher's exact test.

We selected twenty-one periapical pathogen genera that are commonly mentioned in the literature (Fujii et al., 2009; Siqueira \& Rocas, 2009; Somma, Castagnola, Bollino, \& Marigo, 2011) and compared their mean loads (mean number of $16 \mathrm{~S}$ rRNA copies) and prevalence in the placental and fetal membrane tissues between participants who did not have and who had PAI. The selected bacteria genera were Actinomyces, Anaeroglobus, Atopobium, Bacteroides, Dialister, Enterococcus, Eubacterium, Filifactor, Fusobacterium, Mogibacterium, Olsenella, Parvimonas, Peptostreptococcus, Porphyromonas, Prevotella, Propionibacterium, Pseudoramibacter, Streptococcus, Tannerella, Treponema and Veillonella. Bacterial OTUs were first filtered at $0.01 \%$ mean relative abundance across samples and then clustered by genus. Tables of the particular genera were produced for women with both a sample and the dental assessment data. In the group comparisons, the MannWhitney U-test was used for the means and Fisher's exact test for the prevalence.

We assessed also the mean bacterial loads (mean number of $16 \mathrm{~S}$ rRNA gene copies) of each bacteria genera found in the placentas or membranes of the mothers without or with PAI. Comparison of the mean values between the infection groups was made with Mann-Whitney U-test. The analysis was adjusted by Benjamini-Hochberg equation to control the false discovery rate due to the number of comparisons.

This article is protected by copyright. All rights reserved. 


\section{RESULTS}

A total of 1391 participants were enrolled in the iLiNS-DYAD study. Of those, 1229 (88.4\%) completed the oral health examination between May 2011 and August 2013. After excluding mothers with twins and those who completed the oral examination later than 6 wk after delivery, 1024 (79.6\%) participants were included in the analyses (supplementary figure 1.). The baseline characteristics of the included and excluded participants were similar except that the included women were on average slightly older ( 25 vs 24 y), less often primiparous ( $17.8 \%$ vs $33.3 \%$ ) or malaria positive ( $21.4 \%$ vs $28.1 \%$ ), and had a higher mean score for socio-economic status (0.46 vs 0.13) and lower mean BMI (22.1 vs 22.4) (supplementary table 2.). The participant flow and the baseline characteristics have been published earlier (Harjunmaa et al., 2015).

Among the included participants, the mean (SD) duration of pregnancy was 39.4 (2.3) gw, birth weight was 2979 (430) g and neonatal length was $49.7(2.2) \mathrm{cm}$. The prevalence of PAI was $23.5 \%$ $(n=241)$. Mean (SD) time between delivery and oral examination was16.0 (8.0) days. The mean values for the laboratory measurements, histology findings and bacterial DNA of the participants are presented in table 1.

\section{Markers of a direct pathway}

There were no statistically significant differences between the PAl categories in any of the placental or fetal membrane histology-based inflammation markers. However, although statistically nonsignificant, the relative risk was usually higher when comparing the severe PAI group to the mild-tomoderate or no PAI groups, or the mild-to-moderate group to the no PAI group (table 2.).Similarly, no statistically significant differences were detected between the PAl categories in the prevalence of

This article is protected by copyright. All rights reserved. 
any bacteria in the placental (healthy $66.7 \%$, mild-to-moderate $74.0 \%$ and severe $58.5 \% \mathrm{p}=0.242$ ) or membrane (healthy $44.8 \%$, mild-to-moderate $53.7 \%$ and severe $38.6 \% \mathrm{p}=0.470$ ) samples.

Out of the selected 21 bacteria genera that are commonly involved in PAI, 13 were found in both the fetal membranes and the placental tissues. However, there were no statistically significant differences between the groups of women with and without PAI in the mean bacterial loads (mean number of $16 \mathrm{~S}$ rRNA copies) (table 3.) or in the prevalence of any of those bacteria genera (supplementary table 3.) that were found in at least 10 participants in the placental tissues. Similarly, no statistically significant differences between the PAI groups were found in the mean bacterial loads even when any bacteria genera that were found from the placental or membrane tissues were analyzed (data not shown).

\section{Markers of an indirect pathway}

There was a positive, dose-dependent association between PAl severity and the mean plasma concentrations of CRP, AGP and salivary concentration of cortisol at 36 gw. Compared to the no PAI group, women in the severe PAl group had $8.07(0.40-15.75) \mathrm{mg} / \mathrm{L}$ higher mean CRP and $1.90 \mathrm{nmol} / \mathrm{L}$ higher mean cortisol concentration, and women in the mild-to-moderate PAl group had $0.84 \mathrm{nmol} / \mathrm{L}$ higher mean cortisol concentration at 36 wk. No association was found with the $14-20$ wk samples (Table 4).No association was found with the 14-20wk samples (Table 4).

The patterns in the prevalence of elevated CRP, AGP and cortisol by PAI categories were similar to those for the continuous variables, except that the differences were statistically significant only for high cortisol at $36 \mathrm{gw}$ (healthy $21.3 \%$, mild-to-moderate $28.7 \%$, severe $45.8 \%, \mathrm{p}=0.033$ ) (data not shown).

This article is protected by copyright. All rights reserved. 


\section{Mediation of PAI - birth outcome association by systemic inflammation markers and cortisol}

In the primary analyses, women with PAI had $0.4 \mathrm{wk}$ shorter mean pregnancy duration $(p=0.015)$ and infants with $90 \mathrm{~g}$ lower mean BW $(\mathrm{p}=0.009)$ and $0.56 \mathrm{~cm}$ shorter mean neonatal length $(p=0.002)$ compared to those who did not have PAI. Adjustment of the regression model for maternal AGP concentration at 36wk reduced the difference in means by $0.1 \mathrm{wk}$ in the duration of pregnancy, $15 \mathrm{~g}$ in BW and $0.08 \mathrm{~cm}$ in neonatal length, and increased the $\mathrm{p}$-values for each of the models. Adjustment for salivary cortisol concentration at $36 \mathrm{wk}$ reduced the difference in pregnancy duration by 0.1 wk, BW by $10 \mathrm{~g}$ and neonatal length by $0.02 \mathrm{~cm}$. When adjusting for both AGP and cortisol at the same time the results did not differ substantially from the AGP only adjustment, i.e. the effects were not additive. Adjustment for plasma CRP concentration or maternal severe chorioamnionitis did not markedly affect the strength of the association with any of the outcomes (table 5.).

\section{DISCUSSION}

We aimed to investigate whether infection in placenta or within the chorioamniotic membranes (direct pathway) or systemic inflammation (indirect pathway) mediate the association between maternal PAI and shortened pregnancy duration, lower birth weight or smaller neonatal size. We did not find any evidence of a direct pathway linking periapical infection and pregnancy outcomes. However, PAI was associated with CRP, AGP and cortisol at $36 \mathrm{gw}$ in a dose-dependent manner. The associations between PAI and the adverse pregnancy outcomes were partially mediated by AGP and cortisol.

This article is protected by copyright. All rights reserved. 


\section{Strengths and weaknesses}

Strengths of this study include a large sample size, rigorous quality control, multiple biological samples collected at various time points during pregnancy and after delivery, and clinical and x-raybased oral health assessment that allowed high quality diagnostics. The main weaknesses were some missing biological sample data, some differences in baseline characteristics between the participants who were included in analyses and those lost to follow-up, e.g. primiparity, and our inability to document the oral health status at baseline and immediately after delivery i.e. at the same time as the biological sample collection, due to ethical restrictions (e.g., exposure to $x$-rays) and complexity of the study logistics in this low-resource context. In addition, the placental tissue of mothers who delivered very preterm was mostly not available, and naturally they did not undergo the $36 \mathrm{gw}$ sample collection. To reduce bias due to the loss-to-follow-up, we conducted adjusted analyses that included the baseline characteristics that distinguished the excluded and included participants, and imputed the missing data with multiple imputations (excluding bacterial DNA). PAI was almost entirely related to large caries lesions that take several years to develop and are rarely treated in this low-resource setting, thus it is unlikely that their prevalence after delivery differed substantially from that at enrolment or $36 \mathrm{gw}$. Finally, since the research team did not have the responsibility of providing the intermittent malaria treatment to the mothers, it was not possible to confirm if some participants received less than the standard amount of three doses.

\section{Placental infection}

In previous studies, bacteria, unequivocally demonstrated to have originated from infected root canals, have been isolated from blood (Debelian, Olsen, \& Tronstad, 1996), (Debelian et al., 1996), and in many studies found in the feto-placental unit, especially in preterm births (Han \& Wang, 2013). While we did detect bacteria in placental tissue, previously reported to have originated from

This article is protected by copyright. All rights reserved. 
the oral cavity, we did not see any differences between those who did or did not have PAI.

Furthermore, no differences were found in placental inflammation. This may be explained by the lack of samples from the pregnancies that ended in miscarriage and very early deliveries that took place at home where the tissues were discharged.

\section{Systemic inflammation}

Our study supports the earlier findings that PAI may induce systemic inflammatory responses (Gomes et al., 2013; Marton \& Kiss, 2000; Somma et al., 2011), with elevated concentrations of CRP (Gomes et al., 2013) and AGP (de Soet et al., 2003; Glurich et al., 2002). We could not find any earlier studies linking PAI and cortisol concentrations, but cortisol concentrations have previously been associated with increased growth and virulence of oral pathogens (Jentsch, Marz, \& Kruger, 2013). In our study, the associations between PAI and the inflammatory markers and cortisol were stronger at $36 \mathrm{wk}$ than earlier in gestation. We believe that this finding relates to the alteration in the immune system during pregnancy. In early gestation the host immune responses are able to control local, low-grade infections, but pregnancy-related attenuation in the immune response increases the susceptibility to and consequences of infections in later gestation (Kourtis, Read, \& Jamieson, 2014). The underlying mechanisms include limited T-cell activity (Taylor, Sullivan, Eblen, \& Gercel-Taylor, 2002), decreased neutrophil functions and antibody production (Zachariasen, 1993), and hormonal changes which contribute to increased vascular permeability and bone resorption (Komm et al., 1988).

This article is protected by copyright. All rights reserved. 
Systemic inflammation, measured by elevated CRP concentration (Pitiphat et al., 2005; Tjoa et al., 2003), and salivary cortisol concentrations (Giurgescu, 2009) during pregnancy have previously been associated with shortened duration of gestation and IUGR. In line with those results, inflammation was associated with pregnancy outcomes also in our study sample. We also found that the association between PAI and adverse pregnancy outcomes was attenuated modestly when AGP or cortisol concentration was added in regression models, suggesting partial mediation of the association by the inflammatory pathway. The modest association may be related to the missed "before delivery" samples from those who delivered very early and who may have had more marked inflammation. Another important consideration is that our analyses were limited to the available markers, which may not have fully reflected systemic inflammation. Some oral-diseases-related salivary interleukins, immunoglobulins or metalloproteinases, released from infected periapical tissues (Gomes et al., 2013; Javaid, Ahmed, Durand, \& Tran, 2016) and known to be associated with adverse pregnancy outcomes (Romero et al., 2014), might have been more sensitive markers.

\section{CONCLUSIONS}

The study findings suggest that PAI causes adverse pregnancy outcomes partially via an indirect pathway of systemic inflammation but not through a direct pathway of local placental infection. Further studies are needed to investigate whether the associations between PAI, elevated inflammatory markers and adverse birth outcomes are more pronounced when very early preterm deliveries are included. It is also important to study other inflammatory pathways and the impact of PAl elimination on pregnancy outcomes in future studies.

This article is protected by copyright. All rights reserved. 


\section{ACKNOWLEDGEMENTS}

This publication is based on research funded in part by the Office of Health, Infectious Diseases, and Nutrition, Bureau for Global Health, U.S. Agency for International Development (USAID) under terms of Cooperative Agreement No. AID-OAA-A-12-00005, through the Food and Nutrition Technical Assistance III Project (FANTA), managed by FHI 360. Additional funding was provided by the Bill \& Melinda Gates Foundation through a grant to the University of California, Davis. UH received personal working grant also from the Finnish cultural Foundation and Finnish Dental Society Apollonia. Planmega Ltd provided the $\mathrm{x}$-ray machine for nominal price and $3 \mathrm{M}$ donated materials for dental treatment of the participants. The findings and conclusions contained within are those of the authors and do not necessarily reflect positions or policies of USAID, the United States Government, the Bill \& Melinda Gates Foundation, or the other funders.

We thank the study participants, the local communities, our research personnel at the study sites and the iLiNS Project extended research team for their positive attitude and support during the study. We particularly thank Simeon Mulewa and Davie Charlie for the clinical oral health data collection, and the iLiNS Project Steering Committee members and Project Manager Mary Arimond (http://ilins.org) for technical support.

\section{CONFLICTS OF INTERESTS}

None to declare

\section{AUTHOR CONTRIBUTIONS}

The authors' responsibilities were as follows: UH, UA, NJK, KGD, KM and PA designed research; UH, RD, JJ, SK, CPS, JMJ, LS and PA conducted research; UH, LH, RD and LS analysed data; UH and PA wrote the paper with critical input and comments from all other authors. All authors read and approved the final manuscript.

\section{REFERENCES}

\section{References}

Aagaard, K., Ma, J., Antony, K. M., Ganu, R., Petrosino, J., \& Versalovic, J. (2014). The placenta harbors a unique microbiome. Science Translational Medicine, 6(237), 237ra65. doi:10.1126/scitransImed.3008599 [doi]

This article is protected by copyright. All rights reserved. 
Ashorn, P., Alho, L., Ashorn, U., Cheung, Y., Dewey, K., Harjunmaa, U., . . Maleta, K. (2015). The impact of lipid-based nutrient supplement provision to pregnant women on newborn size in rural Malawi: A randomised controlled trial. Am.J.Clin.Nutr., 101, 387-97.

Bellavance, M. A., \& Rivest, S. (2014). The HPA - immune axis and the immunomodulatory actions of glucocorticoids in the brain. Frontiers in Immunology, 5, 136. doi:10.3389/fimmu.2014.00136 [doi]

Chang, H. H., Larson, J., Blencowe, H., Spong, C. Y., Howson, C. P., Cairns-Smith, S., . . Born Too Soon preterm prevention analysis group. (2013). Preventing preterm births: Analysis of trends and potential reductions with interventions in 39 countries with very high human development index. Lancet, 381(9862), 223-234. doi:10.1016/S0140-6736(12)61856-X [doi]

de Soet, J. J., Schriks, M. C., Kratz, E., Poland, D. C., van Dijk, W., \& van Amerongen, W. E. (2003). Dental caries related to plasma IgG and alpha1-acid glycoprotein. Caries Research, 37(2), 79-84. doi:69014 [doi]

Debelian, G. J., Olsen, I., \& Tronstad, L. (1996). Electrophoresis of whole-cell soluble proteins of microorganisms isolated from bacteremias in endodontic therapy. European Journal of Oral Sciences, 104(5-6), 540-546.

Doyle, R. M., Harris, K., Kamiza, S., Harjunmaa, U., Ashorn, U., Nkhoma, M., . . Klein, N. (2017). Bacterial communities found in placental tissues are associated with severe chorioamnionitis and adverse birth outcomes. PloS One, 12(7), e0180167. doi:10.1371/journal.pone.0180167 [doi]

Fujii, R., Saito, Y., Tokura, Y., Nakagawa, K. I., Okuda, K., \& Ishihara, K. (2009). Characterization of bacterial flora in persistent apical periodontitis lesions. Oral Microbiology and Immunology, 24(6), 502-505. doi:10.1111/j.1399-302X.2009.00534.x [doi]

This article is protected by copyright. All rights reserved. 
Giurgescu, C. (2009). Are maternal cortisol levels related to preterm birth? Journal of Obstetric, Gynecologic, and Neonatal Nursing : JOGNN, 38(4), 377-390. doi:10.1111/j.15526909.2009.01034.x [doi]

Glurich, I., Grossi, S., Albini, B., Ho, A., Shah, R., Zeid, M., . . De Nardin, E. (2002). Systemic inflammation in cardiovascular and periodontal disease: Comparative study. Clinical and Diagnostic Laboratory Immunology, 9(2), 425-432.

Goldenberg, R. L., Culhane, J. F., lams, J. D., \& Romero, R. (2008). Epidemiology and causes of preterm birth. Lancet, 371(9606), 75-84. doi:10.1016/S0140-6736(08)60074-4 [doi]

Gomes, M. S., Blattner, T. C., Sant'Ana Filho, M., Grecca, F. S., Hugo, F. N., Fouad, A. F., \& Reynolds, M. A. (2013). Can apical periodontitis modify systemic levels of inflammatory markers? A systematic review and meta-analysis. Journal of Endodontics, 39(10), 1205-1217. doi:10.1016/j.joen.2013.06.014 [doi]

Han, Y. W., \& Wang, X. (2013). Mobile microbiome: Oral bacteria in extra-oral infections and inflammation. Journal of Dental Research, 92(6), 485-491. doi:10.1177/0022034513487559 [doi]

Harjunmaa, U., Jarnstedt, J., Alho, L., Dewey, K. G., Cheung, Y. B., Deitchler, M., . . Ashorn, P. (2015). Association between maternal dental periapical infections and pregnancy outcomes: Results from a cross-sectional study in Malawi. Tropical Medicine \& International Health : TM \& IH, doi:10.1111/tmi.12579 [doi]

Javaid, M. A., Ahmed, A. S., Durand, R., \& Tran, S. D. (2016). Saliva as a diagnostic tool for oral and systemic diseases. Journal of Oral Biology and Craniofacial Research, 6(1), 66-75. doi:10.1016/j.jobcr.2015.08.006 [doi]

This article is protected by copyright. All rights reserved. 
Jentsch, H. F., Marz, D., \& Kruger, M. (2013). The effects of stress hormones on growth of selected periodontitis related bacteria. Anaerobe, 24, 49-54. doi:10.1016/j.anaerobe.2013.09.001 [doi]

Komm, B. S., Terpening, C. M., Benz, D. J., Graeme, K. A., Gallegos, A., Korc, M., . . Haussler, M. R. (1988). Estrogen binding, receptor mRNA, and biologic response in osteoblast-like osteosarcoma cells. Science (New York, N.Y.), 241(4861), 81-84.

Kourtis, A. P., Read, J. S., \& Jamieson, D. J. (2014). Pregnancy and infection. The New England Journal of Medicine, 370(23), 2211-2218. doi:10.1056/NEJMra1213566 [doi]

Lee, A. C., Katz, J., Blencowe, H., Cousens, S., Kozuki, N., Vogel, J. P., . . CHERG SGA-Preterm Birth Working Group. (2013). National and regional estimates of term and preterm babies born small for gestational age in 138 low-income and middle-income countries in 2010. The Lancet Global Health, 1(1), e26-36. doi:10.1016/S2214-109x(13)70006-8 [doi]

Liu, L., Johnson, H. L., Cousens, S., Perin, J., Scott, S., Lawn, J. E., . . Child Health Epidemiology Reference Group of WHO and UNICEF. (2012). Global, regional, and national causes of child mortality: An updated systematic analysis for 2010 with time trends since 2000. Lancet (London, England), 379(9832), 2151-2161. doi:10.1016/S0140-6736(12)60560-1 [doi]

Marcenes, W., Kassebaum, N. J., Bernabe, E., Flaxman, A., Naghavi, M., Lopez, A., \& Murray, C. J. (2013). Global burden of oral conditions in 1990-2010: A systematic analysis. Journal of Dental Research, 92(7), 592-597. doi:10.1177/0022034513490168; 10.1177/0022034513490168

Marton, I. J., \& Kiss, C. (2000). Protective and destructive immune reactions in apical periodontitis. Oral Microbiology and Immunology, 15(3), 139-150. doi:omi150301 [pii]

This article is protected by copyright. All rights reserved. 
Nair, P. N. (2004). Pathogenesis of apical periodontitis and the causes of endodontic failures. Critical Reviews in Oral Biology and Medicine : An Official Publication of the American Association of Oral Biologists, 15(6), 348-381. doi:15/6/348 [pii]

Pitiphat, W., Gillman, M. W., Joshipura, K. J., Williams, P. L., Douglass, C. W., \& Rich-Edwards, J. W. (2005). Plasma C-reactive protein in early pregnancy and preterm delivery. American Journal of Epidemiology, 162(11), 1108-1113. doi:kwi323 [pii]

Romero, R., Dey, S. K., \& Fisher, S. J. (2014). Preterm labor: One syndrome, many causes. Science (New York, N.Y.), 345(6198), 760-765. doi:10.1126/science.1251816 [doi]

Saigal, S., \& Doyle, L. W. (2008). An overview of mortality and sequelae of preterm birth from infancy to adulthood. Lancet, 371(9608), 261-269. doi:10.1016/S0140-6736(08)60136-1 [doi]

Siqueira, J. F.Jr, \& Rocas, I. N. (2009). Diversity of endodontic microbiota revisited. Journal of Dental Research, 88(11), 969-981. doi:10.1177/0022034509346549 [doi]

Somma, F., Castagnola, R., Bollino, D., \& Marigo, L. (2011). Oral inflammatory process and general health. part 2: How does the periapical inflammatory process compromise general health? European Review for Medical and Pharmacological Sciences, 15(1), 35-51.

Stewart, C. P., Oaks, B. M., Laugero, K. D., Ashorn, U., Harjunmaa, U., Kumwenda, C., . . Dewey, K. G. (2015). Maternal cortisol and stress are associated with birth outcomes, but are not affected by lipid-based nutrient supplements during pregnancy: An analysis of data from a randomized controlled trial in rural Malawi. BMC Pregnancy and Childbirth, 15, 346-015-0793-8. doi:10.1186/s12884-015-0793-8 [doi]

This article is protected by copyright. All rights reserved. 
Taylor, D. D., Sullivan, S. A., Eblen, A. C., \& Gercel-Taylor, C. (2002). Modulation of T-cell CD3-zeta chain expression during normal pregnancy. Journal of Reproductive Immunology, 54(1-2), 1531. doi:S0165037801000675 [pii]

Tjoa, M. L., van Vugt, J. M., Go, A. T., Blankenstein, M. A., Oudejans, C. B., \& van Wijk, I. J. (2003). Elevated C-reactive protein levels during first trimester of pregnancy are indicative of preeclampsia and intrauterine growth restriction. Journal of Reproductive Immunology, 59(1), 29-37. doi:S0165037802000852 [pii]

van Buuren, S., Boshuizen, H. C., \& Knook, D. L. (1999). Multiple imputation of missing blood pressure covariates in survival analysis. Statistics in Medicine, 18(6), 681-694. doi:10.1002/(SICI)1097-0258(19990330)18:63.0.CO;2-R [pii]

Voltolini, C., \& Petraglia, F. (2014). Neuroendocrinology of pregnancy and parturition. Handbook of Clinical Neurology, 124, 17-36. doi:10.1016/B978-0-444-59602-4.00002-2 [doi]

Zachariasen, R. D. (1993). The effect of elevated ovarian hormones on periodontal health: Oral contraceptives and pregnancy. Women \& Health, 20(2), 21-30. doi:10.1300/J013v20n02_02 [doi]

Zou, G. (2004). A modified poisson regression approach to prospective studies with binary data. American Journal of Epidemiology, 159(7), 702-706.

This article is protected by copyright. All rights reserved. 
TABLES

Table 1. Proportion of women with evidence of histological inflammation or bacterial infection in placenta, or systemic inflammation

\begin{tabular}{|l|c|}
\hline \multicolumn{1}{|c|}{ Outcome } & $\begin{array}{c}\text { Proportion of } \\
\text { women (n) }\end{array}$ \\
\hline Direct pathway & \\
\hline Chronic placental intervillositis & $1.9 \%(19)$ \\
\hline Acute placental intervillositis & $21.2 \%(217)$ \\
\hline Chorioamnionitis & $19.9 \%(204)$ \\
\hline Bacterial DNA detected in chorioamniotic membranes & $59.2 \%(606)$ \\
\hline Bacterial DNA detected in placental tissues & $38.5 \%(394)$ \\
\hline Indirect pathway & \\
\hline Elevated CRP concentration at 14-20 wk & $39.1 \%(400)$ \\
\hline Elevated CRP concentration at 36wk & $29.7 \%(304)$ \\
\hline Elevated AGP concentration at 14-20 wk & $8.2 \%(84)$ \\
\hline Elevated AGP concentration at 36wk & $23.6 \%(244)$ \\
\hline Elevated cortisol concentration at 14-20 & \\
\hline Elevated cortisol concentration at 36wk & \\
\hline
\end{tabular}

Abbreviations: $\mathrm{PAI}=$ periapical infection, $\mathrm{CRP}=\mathrm{C}$-reactive protein, $\mathrm{AGP}=$ alpha-1-acid glycoprotein, DNA=deoxyribonucleic acid

This article is protected by copyright. All rights reserved. 
Table 2. Prevalence of chronic and acute placenta intervillosis, any chorioamnionitis and severe chorioamnionitis by periapical infection severity.

\begin{tabular}{|c|c|c|c|c|c|c|c|c|c|c|}
\hline \multirow[b]{2}{*}{ Outcome } & \multicolumn{4}{|c|}{$\begin{array}{l}\text { Prevalence of placental inflammation by } \\
\text { participants' PAl status* }\end{array}$} & \multicolumn{2}{|c|}{$\begin{array}{l}\text { Comparison, mild-to- } \\
\text { mod vs no PAl }\end{array}$} & \multicolumn{2}{|c|}{$\begin{array}{c}\text { Comparison, severe vs } \\
\text { no PAI }\end{array}$} & \multicolumn{2}{|c|}{$\begin{array}{l}\text { Comparison, severe vs } \\
\text { mild-to-mod PAI }\end{array}$} \\
\hline & $\begin{array}{l}\text { No PAl } \\
n=783\end{array}$ & $\begin{array}{c}\text { Mild to } \\
\text { Moderate PAI } \\
n=215\end{array}$ & $\begin{array}{c}\text { Severe PAl } \\
n=26\end{array}$ & $\begin{array}{c}\mathrm{P}- \\
\text { value }\end{array}$ & $\begin{array}{l}\text { Risk ratio } \\
(95 \% \mathrm{Cl})\end{array}$ & P-value & $\begin{array}{c}\text { Risk ratio (95 } \\
\% \mathrm{Cl})\end{array}$ & P-value & $\begin{array}{c}\text { Risk ratio (95 } \\
\% \mathrm{Cl})\end{array}$ & P-value \\
\hline $\begin{array}{l}\text { Chronic placental } \\
\text { intervillositis }\end{array}$ & $2.0 \%$ & $2.6 \%$ & $0.0 \%$ & 0.883 & $\begin{array}{c}1.28 \\
(0.43-3.87)\end{array}$ & 0.656 & $n / a$ & $n / a$ & $n / a$ & $\mathrm{n} / \mathrm{a}$ \\
\hline $\begin{array}{l}\text { Acute placental } \\
\text { intervillositis }\end{array}$ & $15.8 \%$ & $13.9 \%$ & $29.9 \%$ & 0.231 & $\begin{array}{c}0.88 \\
(0.54-1.44)\end{array}$ & 0.513 & $\begin{array}{c}1.90 \\
(0.85-4.22)\end{array}$ & 0.116 & $\begin{array}{c}2.15 \\
(0.93-4.97)\end{array}$ & 0.072 \\
\hline $\begin{array}{l}\text { Chorioamnionitis, } \\
\text { any ( }>4 \text { cells) }\end{array}$ & $25.8 \%$ & $28.1 \%$ & $26.7 \%$ & 0.867 & $\begin{array}{c}1.09 \\
(0.79-1.51)\end{array}$ & 0.596 & $\begin{array}{c}1.04 \\
(0.46-2.34)\end{array}$ & 0.934 & $\begin{array}{c}0.95 \\
(0.42-2.15)\end{array}$ & 0.899 \\
\hline $\begin{array}{l}\text { Chorioamnionitis, } \\
\text { severe ( }>25 \text { cells) }\end{array}$ & $11.1 \%$ & $14.6 \%$ & $17.2 \%$ & 0.407 & $\begin{array}{c}1.31 \\
(0.84-2.07)\end{array}$ & 0.237 & $\begin{array}{c}1.55 \\
(0.58-4.14)\end{array}$ & 0.382 & $\begin{array}{c}1.18 \\
(0.44-3.15)\end{array}$ & 0.744 \\
\hline
\end{tabular}

PAI=periapical infection

*Adjusted for HIV status, malaria status, height, body-mass index, age, study site, number of teeth, nutritional intervention group, aenemia, periodontitis status, household assets, oral health examination visit time

This article is protected by copyright. All rights reserved. 
Table 3.Comparison of bacterial loads from selected genera that are commonly found in periapical infectious lesions, in the placenta and fetal membranes, presented by periapical infection status groups

\begin{tabular}{|c|c|c|c|c|c|c|}
\hline \multirow{2}{*}{$\begin{array}{l}\text { Bacterial genera in } \\
\text { placental tissues }\end{array}$} & \multicolumn{3}{|c|}{$\begin{array}{l}\text { Mean Log10 16S rRNA copies (SD) in } \\
\text { placental tissues }\end{array}$} & \multicolumn{3}{|c|}{$\begin{array}{l}\text { Mean Log10 16S rRNA copies (SD) in } \\
\text { fetal membranes }\end{array}$} \\
\hline & $\begin{array}{l}\text { No PAl } \\
\mathrm{n}=641\end{array}$ & $\begin{array}{c}\text { PAI } \\
n=188\end{array}$ & P-value & $\begin{array}{l}\text { No PAl } \\
n=687\end{array}$ & $\begin{array}{c}\text { PAI } \\
n=200\end{array}$ & P-value \\
\hline Actinomyces & $0.10(0.53)$ & $0.03(0.27)$ & 0.070 & $0.02(0.26)$ & $0(0)$ & 0.242 \\
\hline Bacteroides & $0.08(0.53)$ & $0.04(0.37)$ & 0.351 & $0.12(0.72)$ & $0.06(0.40)$ & 0.206 \\
\hline Dialister & $0.02(0.22)$ & $0.02(0.21)$ & 0.938 & $0.08(0.52)$ & $0.07(0.54)$ & 0.893 \\
\hline Enterococcus & $0.21(0.92)$ & $0.16(0.81)$ & 0.559 & $0.35(1.20)$ & $0.23(0.98)$ & 0.173 \\
\hline Fusobacterium & 0.17 (7649) & $0.08(1008)$ & 0.120 & $0.14(0.76)$ & $0.11(0.72)$ & 0.605 \\
\hline Parvimonas & $0.01(0.09)$ & $0.09(0.50)$ & $<0.001$ & $0.12(0.67)$ & $0.17(0.80)$ & 0.394 \\
\hline Peptostreptococcus & $0.16(0.69)$ & $0.16(0.69)$ & 0.952 & $0.32(1.11)$ & $0.47(1.36)$ & 0.131 \\
\hline Porphyromonas & $0.13(0.63)$ & $0.09(0.49)$ & 0.418 & $0.04(0.36)$ & $0.01(0.18)$ & 0.253 \\
\hline Prevotella & $0.72(1.42)$ & $0.82(1.56)$ & 0.398 & $1.18(1.86)$ & $1.20(1.89)$ & 0.869 \\
\hline Propionibacterium & $0.25(0.03)$ & $0.35(0.07)$ & 0.197 & $0.13(0.59)$ & $0.07(0.45)$ & 0.135 \\
\hline Streptococcus & $0.52(1.23)$ & $0.59(1.34)$ & 0.481 & $1.02(1.83)$ & $1.08(1.94)$ & 0.680 \\
\hline Treponema & $0.06(0.41)$ & $0.06(0.42)$ & 0.959 & $0.15(0.73)$ & $0.15(0.73)$ & 0.922 \\
\hline Veillonella & $0.25(0.89)$ & $0.18(0.76)$ & 0.311 & $0.48(1.33)$ & $0.39(1.12)$ & 0.347 \\
\hline
\end{tabular}

PAI=Periapical infection

This article is protected by copyright. All rights reserved. 
Table 4. Mean CRP, AGP and cortisol concentrations at $14-20 w k$ and at $36 \mathrm{wk}$ of pregnancy by maternal periapical infection severity

\begin{tabular}{|c|c|c|c|c|c|c|c|c|c|c|}
\hline \multirow[b]{2}{*}{ Outcome } & \multicolumn{4}{|c|}{$\begin{array}{c}\text { Mean (SD) concentration by participants' } \\
\text { PAl status* }\end{array}$} & \multicolumn{2}{|c|}{$\begin{array}{l}\text { Comparison, mild- } \\
\text { to-mod vs no PAl }\end{array}$} & \multicolumn{2}{|c|}{$\begin{array}{c}\text { Comparison, severe vs } \\
\text { no PAl }\end{array}$} & \multicolumn{2}{|c|}{$\begin{array}{l}\text { Comparison, severe vs } \\
\text { mild-to-mod PAl }\end{array}$} \\
\hline & $\begin{array}{l}\text { No PAI } \\
n=783\end{array}$ & $\begin{array}{c}\text { Mild to } \\
\text { moderate } \\
\text { PAl } \\
n=215\end{array}$ & $\begin{array}{c}\text { Severe } \\
\text { PAI } \\
n=26\end{array}$ & $\begin{array}{c}\mathrm{P}- \\
\text { value }\end{array}$ & $\begin{array}{c}\text { Difference in } \\
\text { means } \\
(95 \% \mathrm{Cl})\end{array}$ & $\begin{array}{c}\text { P- } \\
\text { value }\end{array}$ & $\begin{array}{c}\text { Difference } \\
\text { in means } \\
(95 \% \mathrm{Cl})\end{array}$ & $\begin{array}{c}\text { P- } \\
\text { value }\end{array}$ & $\begin{array}{c}\text { Difference } \\
\text { in means } \\
(95 \% \mathrm{Cl})\end{array}$ & P-value \\
\hline CRP mg/L, 14-20wk & $\begin{array}{c}8.89 \\
(19.13)\end{array}$ & $\begin{array}{c}8.82 \\
(16.00)\end{array}$ & $\begin{array}{c}11.85 \\
(18.93)\end{array}$ & 0.740 & $\begin{array}{c}-0.07 \\
(-3.06-2.93)\end{array}$ & 0.966 & $\begin{array}{c}2.96 \\
(-4.71-10.63)\end{array}$ & 0.449 & $\begin{array}{c}3.03 \\
(-4.75-10.81)\end{array}$ & 0.445 \\
\hline CRP mg/L, 36wk & $\begin{array}{c}6.33 \\
(14.81)\end{array}$ & $\begin{array}{c}8.68 \\
(17.06)\end{array}$ & $\begin{array}{c}14.41 \\
(19.00)\end{array}$ & 0.048 & $\begin{array}{c}2.35 \\
(-0.48-5.18)\end{array}$ & 0.104 & $\begin{array}{c}8.07 \\
(0.40-15.75)\end{array}$ & 0.039 & $\begin{array}{c}5.73 \\
(-2.06-13.51)\end{array}$ & 0.149 \\
\hline AGP g/L, 14-20wk & $\begin{array}{c}0.72 \\
(0.24)\end{array}$ & $\begin{array}{c}0.71 \\
(0.21)\end{array}$ & $\begin{array}{c}0.70 \\
(0.20)\end{array}$ & 0.926 & $\begin{array}{c}0.00 \\
(-0.04-0.03)\end{array}$ & 0.838 & $\begin{array}{c}-0.02 \\
(-0.11-0.08)\end{array}$ & 0.718 & $\begin{array}{c}-0.01 \\
(-0.11-0.08)\end{array}$ & 0.781 \\
\hline AGP g/L, 36wk & $\begin{array}{c}0.57 \\
(0.22)\end{array}$ & $\begin{array}{l}0.60 \\
(0.29)\end{array}$ & $\begin{array}{c}0.69 \\
(0.26)\end{array}$ & 0.040 & $\begin{array}{c}0.03 \\
(-0.01-0.07)\end{array}$ & 0.140 & $\begin{array}{c}0.12 \\
(0.02-0.23)\end{array}$ & 0.022 & $\begin{array}{c}0.09 \\
(-0.02-0.20)\end{array}$ & 0.093 \\
\hline $\begin{array}{l}\text { Cortisol nmol/L, 14- } \\
\text { 20wk }\end{array}$ & $\begin{array}{c}5.62 \\
(3.79)\end{array}$ & $\begin{array}{c}5.60 \\
(3.06)\end{array}$ & $\begin{array}{c}5.41 \\
(2.65)\end{array}$ & 0.963 & $\begin{array}{c}0.03 \\
(-0.56-0.63)\end{array}$ & 0.910 & $\begin{array}{c}-0.18 \\
(-1.70-1.34)\end{array}$ & 0.781 & $\begin{array}{c}-0.21 \\
(-1.71-1.29)\end{array}$ & 0.818 \\
\hline Cortisol nmol/L, 36wk & $\begin{array}{c}7.97 \\
(2.91)\end{array}$ & $\begin{array}{c}8.85 \\
(4.62)\end{array}$ & $\begin{array}{c}9.87 \\
(3.24)\end{array}$ & 0.006 & $\begin{array}{c}0.84 \\
(0.19-1.50)\end{array}$ & 0.012 & $\begin{array}{c}1.90 \\
(0.25-3.36)\end{array}$ & 0.024 & $\begin{array}{c}1.06 \\
(-0.63-2.75)\end{array}$ & 0.218 \\
\hline
\end{tabular}

Abbreviations: $\mathrm{CRP}=\mathrm{C}$-reactive protein, AGP=Alpha-1-acid glycoprotein, $\mathrm{PAl}=$ periapical infection

Mild to moderate PAI=1-3 lesions, severe PAl>3lesions

*Adjusted for HIV status, malaria status, height, body-mass index, age, study site, number of teeth, nutritional intervention group, aenemia, periodontitis status, household assets, oral health examination visit time. Cortisol adjusted also for saliva collection time and time from last meal

This article is protected by copyright. All rights reserved. 
Table 5. Continuous birth outcomes by periapical infection status, adjusted for AGP, CRP, cortisol or both AGP and cortisol at 36gw, or chorioamnionitis

\begin{tabular}{|c|c|c|c|c|c|c|c|c|c|c|c|c|c|c|}
\hline \multirow[b]{2}{*}{ Outcome } & \multicolumn{4}{|c|}{ Primary analysis* } & \multicolumn{2}{|c|}{ Adjusted for AGP } & \multicolumn{2}{|c|}{ Adjusted for CRP } & \multicolumn{2}{|c|}{$\begin{array}{c}\text { Adjusted for } \\
\text { cortisol }\end{array}$} & \multicolumn{2}{|c|}{$\begin{array}{c}\text { Adjusted for AGP } \\
\text { and cortisol }\end{array}$} & \multicolumn{2}{|c|}{$\begin{array}{l}\text { Adjusted for severe } \\
\text { chorioamnionitis }\end{array}$} \\
\hline & $\begin{array}{l}\text { Women } \\
\text { without } \\
\text { PAI } \\
(n=783)\end{array}$ & $\begin{array}{l}\text { Women } \\
\text { with PAI } \\
(n=241)\end{array}$ & $\begin{array}{l}\text { Difference } \\
\text { in means } \\
(95 \% \mathrm{Cl})\end{array}$ & P-value & $\begin{array}{l}\text { Diff. in } \\
\text { means } \\
(95 \% \mathrm{Cl})\end{array}$ & P-value & $\begin{array}{l}\text { Diff. in } \\
\text { means } \\
(95 \% \mathrm{Cl})\end{array}$ & P-value & $\begin{array}{l}\text { Diff. in } \\
\text { means } \\
(95 \% \mathrm{Cl})\end{array}$ & P-value & $\begin{array}{l}\text { Diff. in } \\
\text { means } \\
(95 \% \mathrm{Cl})\end{array}$ & P-value & $\begin{array}{l}\text { Diff. in } \\
\text { means } \\
(95 \% \mathrm{Cl})\end{array}$ & P-value \\
\hline $\begin{array}{l}\text { Pregnancy } \\
\text { duration } \\
\text { (SD), gw }\end{array}$ & $\begin{array}{c}39.5 \\
(2.05)\end{array}$ & $\begin{array}{c}39.1 \\
(2.60)\end{array}$ & $\begin{array}{c}-0.4 \\
(-0.8 \text { to - } \\
0.1)\end{array}$ & 0.015 & $\begin{array}{c}-0.3 \\
(-0.7 \text { to }- \\
0.0)\end{array}$ & 0.049 & $\begin{array}{c}-0.4 \\
(-0.8 \text { to - } \\
0.1)\end{array}$ & 0.021 & $\begin{array}{c}-0.3 \\
(-0.7 \text { to } \\
0.0)\end{array}$ & 0.056 & $\begin{array}{c}-0.3 \\
(-0.7 \text { to } \\
0.1)\end{array}$ & 0.097 & $\begin{array}{c}-0.4 \\
(-0.7 \text { to - } \\
0.1)\end{array}$ & 0.022 \\
\hline $\begin{array}{l}\text { Birth } \\
\text { weight (SD), } \\
\text { g }\end{array}$ & $\begin{array}{l}2982 \\
(426)\end{array}$ & $\begin{array}{l}2891 \\
(415)\end{array}$ & $\begin{array}{c}-90 \\
(-157 \text { to }- \\
22)\end{array}$ & 0.009 & $\begin{array}{c}-75 \\
(-142 \text { to }- \\
8)\end{array}$ & 0.028 & $\begin{array}{c}-85 \\
(-153 \text { to }- \\
17)\end{array}$ & 0.014 & $\begin{array}{c}-80 \\
(-149 \text { to }- \\
10)\end{array}$ & 0.024 & $\begin{array}{c}-70 \\
(-139 \text { to }- \\
2)\end{array}$ & 0.043 & $\begin{array}{c}-86 \\
(-153 \text { to } 18)\end{array}$ & 0.013 \\
\hline
\end{tabular}

This article is protected by copyright. All rights reserved. 


\begin{tabular}{|c|c|c|c|c|c|c|c|c|c|c|c|c|c|c|}
\hline WAZ (SD) & $\begin{array}{l}-0.56 \\
(1.03)\end{array}$ & $\begin{array}{l}-0.73 \\
(1.07)\end{array}$ & $\begin{array}{c}-0.19 \\
(-0.35 \text { to }- \\
0.02)\end{array}$ & 0.026 & $\begin{array}{c}-0.14 \\
(-0.31 \text { to } \\
0.02)\end{array}$ & 0.077 & $\begin{array}{c}-0.17 \\
(-0.34 \text { to }- \\
0.01)\end{array}$ & 0.040 & $\begin{array}{c}-0.17 \\
(-0.34 \text { to }- \\
0.00)\end{array}$ & 0.047 & $\begin{array}{c}-0.14 \\
(-0.31 \text { to }- \\
0.02)\end{array}$ & 0.086 & $\begin{array}{c}-0.18 \\
(-0.34 \text { to }- \\
0.01)\end{array}$ & 0.035 \\
\hline $\begin{array}{l}\text { Neonatal } \\
\text { Length, cm } \\
\text { (SD) }\end{array}$ & $\begin{array}{c}49.7 \\
(2.19)\end{array}$ & $\begin{array}{r}49.2 \\
(2.28)\end{array}$ & $\begin{array}{c}-0.56 \\
(-0.92 \text { to }- \\
0.21)\end{array}$ & 0.002 & $\begin{array}{c}-0.48 \\
(-0.83 \text { to }- \\
0.13)\end{array}$ & 0.007 & $\begin{array}{c}-0.54 \\
(-0.90 \text { to }- \\
0.18)\end{array}$ & 0.003 & $\begin{array}{c}-0.54 \\
(-0.90 \text { to }- \\
0.17)\end{array}$ & 0.004 & $\begin{array}{c}-0.49 \\
(-0.84 \text { to }- \\
0.13)\end{array}$ & 0.008 & $\begin{array}{c}-0.54 \\
(-0.89 \text { to }- \\
0.19)\end{array}$ & 0.003 \\
\hline LAZ (SD) & $\begin{array}{l}-0.98 \\
(1.10)\end{array}$ & $\begin{array}{l}-1.27 \\
(1.12)\end{array}$ & $\begin{array}{c}-0.29 \\
(-0.47 \text { to }- \\
0.11)\end{array}$ & 0.001 & $\begin{array}{l}-0.25 \\
-0.42 \text { to }- \\
0.07)\end{array}$ & 0.005 & $\begin{array}{c}-0.27 \\
(-0.46 \text { to }- \\
0.10)\end{array}$ & 0.002 & $\begin{array}{c}-0.28 \\
(-0.47 \text { to }- \\
0.10)\end{array}$ & 0.002 & $\begin{array}{c}-0.26 \\
(-0.43 \text { to }- \\
0.08)\end{array}$ & 0.005 & $\begin{array}{c}-0.28 \\
(-0.46 \text { to }- \\
0.10)\end{array}$ & 0.002 \\
\hline Head Z (SD) & $\begin{array}{l}-0.15 \\
(1.15)\end{array}$ & (1.24) & $\begin{array}{c}-0.22 \\
(-0.41 \text { to }- \\
0.04)\end{array}$ & 0.017 & $\begin{array}{c}-0.18 \\
(-0.37 \text { to } \\
0.00)\end{array}$ & 0.051 & $\begin{array}{c}-0.21 \\
(-0.41 \text { to }- \\
0.03)\end{array}$ & 0.024 & $\begin{array}{c}-0.22 \\
(-0.41 \text { to }- \\
0.03)\end{array}$ & 0.026 & $\begin{array}{c}-0.19 \\
(-0.41 \text { to }- \\
0.03)\end{array}$ & 0.049 & $\begin{array}{c}-0.21 \\
(-0.5 \text { to - } \\
0.03)\end{array}$ & 0.022 \\
\hline
\end{tabular}

PAI=Periapical infection, AGP=Alpha-1-acid glycoprotein, CRP=C-reactive protein, WAZ=weight-for-age $z$-score, LAZ=length-for-age $z$-score, Head Z=head circumference-forage z-score

*Adjusted for HIV status, malaria status, height, body-mass index, age, study site, number of teeth, nutritional intervention group, aenemia, periodontitis status, household assets, oral health examination visit time

This article is protected by copyright. All rights reserved. 